\title{
Immunohistochemical visualization of pro-inflammatory cytokines and enzymes in ovarian tumors
}

\author{
Danuta Plewka ${ }^{*}$, Anna E. Kowalczyk ${ }^{*}$, Beata Jakubiec-Bartnik ${ }^{3}$, Michal Morek ${ }^{3}$, \\ Edyta Bogunia ${ }^{3}$, Andrzej Kmiec ${ }^{4}$, Piotr M. Wierzbicki ${ }^{5}$, Andrzej Plewka ${ }^{3}$
}

${ }^{1}$ Department of Cytophysiology, Chair of Histology and Embryology, Medical University of Silesia, Katowice, Poland

${ }^{2}$ Department of Human Histology and Embryology, Faculty of Medical Sciences, University of Warmia and Mazury, Olsztyn, Poland

${ }^{3}$ Department of Proteomics, Medical University of Silesia, Sosnowiec, Poland

${ }^{4}$ Division of Oncological Propaedeutics, Medical University of Gdansk, Gdansk, Poland

${ }^{5}$ Department of Histology, Medical University of Gdansk, Gdansk, Poland

\begin{abstract}
Epithelial ovarian cancer represents one of the most deadly gynaecological neoplasms in developed countries and is a highly heterogeneous disease. Epidemiological studies show that anti-inflammatory drugs reduce the incidence and mortality of several types of cancer, indicating the potential role of pro-inflammatory factors in carcinogenesis. The expression of pro-inflammatory factors in various cancer types, including ovarian cancer, was assessed in many studies, yielding inconsistent results, often due to the histological heterogeneity of various cancers. The aim of the study was to investigate the expression of IL-1, IL-6, TGF- $\beta$, TNF- $\alpha$, COX-2, iNOS, and NF- $\kappa$ B in serous and mucinous ovarian cancers. Ninety cases of ovarian tumors classified into mucous and serous type (45 patients in each group) were selected. Each group was classified into subgroups according to the three stages of tumor differentiation, i.e. into (i) benign, (ii) borderline and (iii) malignant tumors. The presence of proteins of interest in paraffin sections was analysed by immunohistochemistry. The expression of most of the studied factors depended on the histological tumor subtype and the degree of malignancy. Expression of NF- $\kappa$ B appears to be related to the level of the neoplastic differentiation only in the group of serous tumors, while the presence of IL-6 in the mucinous tumor subtype was observed only in the case of benign lesions. Expression of IL-1, TNF- $\alpha$ and COX-2 increased with the stage of the disease in both serous and mucinous tumors. The highest level of TGF- $\beta$ expression was observed in serous borderline tumors. The different levels of iNOS immunoreactivity between the groups of serous and mucinous tumors were observed only in borderline tumors. The results of our study may be helpful in designing therapeutic strategies depending on the type of ovarian cancer. (Folia Histochemica et Cytobiologica 2014, Vol. 52, No. 2, 124-137)
\end{abstract}

Key words: ovarian cancer subtypes; IHC; NF- $\kappa$ B; COX-2; iNOS; TNF- $\alpha$; TGF- $\beta$; IL-1; IL-6

\section{Introduction}

Ovarian cancer is the leading cause of death among gynaecological neoplasms [1,2]. Absence of specific signs/symptoms of the disease and lack of appropriate

Correspondence address: A. Plewka

Department of Proteomics, Medical University of Silesia,

Ostrogorska St. 30, 41-200 Sosnowiec

tel./fax: +48323641440

e-mail: aplewka@sum.edu.pl

"First two authors equally contributed to this paper techniques for population screening causes that in over $70 \%$ of the cases the disease is diagnosed at its advanced stages [3]. Despite significant improvement in conventional therapy the healing rate remains low for majority of ovarian cancer patients. Therefore, the search for new therapeutic strategies targeting specific markers continues to better understand a molecular background to development of ovarian cancer.

It was found that there was an association between chronic inflammation and tumor development and progression since ca. $15 \%$ of all cancers are attributed to inflammatory ethiology [4]. Epithelial ovarian cancers, similarly to other solid tumors, are strictly 
associated with inflammation and its regulation by a complex cytokine/chemokine network. Cytokines are able to regulate growth, signalling, and differentiation of both tumor and stromal cells. It has been suggested that the cytokines produced by cancer cells create optimal growth conditions within the tumor microenvironment, while the cytokines secreted by stromal cells may influence the behaviour of malignant cells [5].

Interleukin-1 (IL-1) and IL-6 represent pleiotropic cytokines which play a significant role in cell proliferation and differentiation, immune protection and haematopoiesis $[6,7]$. They are also involved in malignant transformations and progression of various tumors $[8,9]$. Interleukin-1 stimulates cells on the way of paracrine action to produce IL-6, tumor necrosis factor $\alpha$ (TNF- $\alpha$ ) and transforming growth factor $\beta$ (TGF- $\beta$ ) [5]. Transforming growth factor $\beta 1$ is a multifunctional regulatory polypeptide. Conducted studies suggest a pro-oncogenic role of TGF- $\beta$ in addition to its tumor suppressor role. The actions of TGF- $\beta$ are dependent on several factors including cell type, growth conditions, and the presence of other growth factors [10]. The inflammatory cytokine TNF- $\alpha$ acts as a significant promoter of a tumor. Constitutive TNF- $\alpha$ production by tumor cells may generate and sustain a tumor-promoting cytokine network in the ovarian cancer microenvironment that would aid tumor growth and spread in vivo [11]. Stimulation of the ovarian cancer cell proliferation by IL- 1 can be blocked partially by inhibition of the TNF- $\alpha$ action [12]. Tumor necrosis factor $\alpha$ induces the IL-6 production [13]. Moreover, together with IL-1 TNF- $\alpha$ transcriptionally regulates the expression of inducible nitric oxide synthase (iNOS) [14]. The role of iNOS during tumor development is highly complex. Both promoting and deterring actions have been described, presumably depending upon the local concentration of iNOS within tumor microenvironment [15]. One of the role of iNOS in carcinogenesis is activation of cyclooxygenase 2 (COX-2) [16]. The cyclooxygenase enzyme isoforms 1 and 2 are involved in the conversion of arachidonic acid to prostaglandins and have distinct functions. Cyclooxygenase 1 is constitutively expressed in many tissues, while COX-2 is an inducible enzyme expressed only in response to stimuli, such as mitogens, cytokines, growth factors or hormones, and has pro-inflammatory function. It plays an important role in tumorigenesis; COX-2 overexpression is associated with apoptosis inhibition, increased invasive and metastatic potential, and neoangiogenesis. Moreover, it has also been hypothesized that overexpression of COX-2 could impair host immune response $[17,18]$.
Although many studies have been conducted to evaluate the expression of COX-2 in ovarian cancer, their results with regard to the association between $\mathrm{COX}-2$ expression and histological types, prognostic factors, response to treatment and outcome are inconsistent. Cyclooxygenase 2 expression is induced also by IL-1 and TNF- $\alpha$. Sakamoto et al. [19] reported that TNF$-\alpha$-induced COX-2 expression was under the control of NF- $\kappa \mathrm{B}$ pathway in the ovarian carcinoma. Nuclear factor $\kappa \mathrm{B}(\mathrm{NF}-\kappa \mathrm{B})$ is a transcription factor known to promote tumorigenesis. The oncogenic function of NF- $\kappa \mathrm{B}$ is mainly due to its effect on activation of multiple target genes involved in antiapoptosis, cell-cycle progression, and angiogenesis. The fact that NF- $\kappa$ B mediates the expression of various survival genes makes it an important target for cancer chemotherapy. However, NF- $\kappa \mathrm{B}$ is also known to be proapoptotic and may potentially function as a tumor suppressor [20]. It was previously proposed that NF- $\kappa \mathrm{B}$ might be required for paclitaxel-induced cell death [21]. However, most reports suggest that paclitaxel-induced NF- $\kappa \mathrm{B}$ activity mediates survival signals that counteract apoptosis [22]. Furthermore, $\mathrm{NF}-\kappa \mathrm{B}$ inhibitor sensitizes human ovarian cancer cells to the effect of paclitaxel [22], and cisplatin [23]. It seems possible that the function of NF- $\kappa \mathrm{B}$ depends on the tumor type. The activity of NF- $\kappa \mathrm{B}$ is tightly controlled by several regulatory proteins, e.g. TNF- $\alpha$ or IL-1, and the genes regulated by NF- $\kappa \mathrm{B}$ involve those coding for cytokines (e.g. IL-1, IL-6 or TNF- $\alpha$ ) [24-27].

Previous studies indicate that each of the histological subtypes of ovarian cancer may be associated with distinct morphologic and molecular genetic alterations [28, 29], suggesting that different genes or molecular pathways and their importance in the progression of various histological subtypes may vary significantly. Although many studies have been carried out for checking the expression of pro-inflammatory agents in various types of cancers, including ovarian cancer, the results of these studies have been often inconsistent. Therefore, the aim of the present study was to investigate the expression of IL-1, IL-6, TGF- $\beta$, TNF- $\alpha$, COX- 2 , iNOS, and NF- $\kappa$ B in the same set of tissues originating from benign, borderline and malignant ovarian tumors developing on the serous or mucinous background.

\section{Material and methods}

Patients. Ninety women with epithelium-derived, ovarian tumors classified into of mucous ( 45 patients, mean age 48.1 \pm 8.4 years, SEM, range 32-56 years) and serous type (45 patients, mean age $46.7 \pm 7.3$ years, range $34-58$ years) were 
included in the study. The two main groups were composed of three subgroups (each contained 15 patients) classified according to the three stages of tumor differentiation: (i) benign tumors, high degree of differentiation, (ii) borderline tumors, medium degree of differentiation, and (iii) malignant tumors, low degree of differentiation. Other clinical details were not available. The exclusion criteria were: diagnosed tumors of the uterus and other organs, patients on hormonal substitute therapy or oral contraceptive drugs, patients with autoimmune diseases, pregnant women and breast-feeding mothers.

Patients underwent laparotomy at Bielsko-Biala Centre of Oncology, Poland. The study was accepted by Bioethical Commission of the Silesian Medical University in Katowice, Poland (KNW/0022/KB/54/10) and written consent was obtained from each patient before treatment.

Immunohistochemical studies. Tissue samples were fixed in $10 \%(\mathrm{v} / \mathrm{v})$ solution of buffered formalin for $24 \mathrm{~h}$ at $4{ }^{\circ} \mathrm{C}$, and then dehydrated, cleared in xylenes and embedded in paraffin. Paraffin sections $(5 \mu \mathrm{m})$ were mounted on silane-coated slides, dewaxed, and rehydrated. The sections were treated with $10 \mathrm{mM}$ citrate buffer, $\mathrm{pH} 6.0$ in water bath $(30 \mathrm{~min}$ at $95^{\circ} \mathrm{C}$ ) for antigen retrieval, then treated with $1.5 \%(\mathrm{v} / \mathrm{v})$ $\mathrm{H}_{2} \mathrm{O}_{2}$ (dissolved in methanol) for $10 \mathrm{~min}$ for quenching of endogenous peroxidase activity, and washed in $10 \mathrm{mM}$ PBS-0.05\% v/v Tween 20, pH 7.5. Nonspecific binding was reduced by incubation in normal goat serum (for rabbit antibodies) or normal horse serum (for mouse antibodies) for $30 \mathrm{~min}$. Then slides were incubated with rabbit anti-TGF- $\beta$, anti-IL-6, anti-TNF- $\alpha$, anti-iNOS (Abcam, Cambridge, MA, USA) and anti-NF- $\kappa$ B (p65) (Santa Cruz Biotech, Dallas, TX, USA) polyclonal antibodies or mouse anti-COX-2 and anti-IL-1 (Santa Cruz Biotech) monoclonal antibodies in a humidified chamber for $22 \mathrm{~h}$ at $4^{\circ} \mathrm{C}$. After washing in PBS-Tween 20 the sections were incubated with biotinylated goat anti-rabbit or horse anti-mouse immunoglobulins (Vector Laboratories, Burlingame, CA, USA) for $30 \mathrm{~min}$, and next with avidin-biotinylated peroxidase complex (Vector) for $30 \mathrm{~min}$. The bound antibodies were visualised with diaminobenzidine (DAB, Vector) in PBS, pH 7.5 according to the manufacturer's instructions. Finally, the tissues were counterstained with Gill's haematoxilin, dehydrated, and cover-slipped. Negative controls were performed by substituting the primary antibodies with rabbit IgG or mouse IgG, respectively.

The immunohistochemical reactions were documented by 10 photographs taken from two representative histological slides of each patient using an Eclipse E200 microscope with DS-Fi1 digital camera (Nikon, Tokyo, Japan).

Optical density analysis. In each positively stained cell, the intensity of staining was measured as the optical density of the reaction product, with the image analysis program NIS AR (Nikon). For each analysed area an average optical density was calculated [30]. Three sections for every studied protein and every patient were analysed. In each section ten randomly selected fields were examined. Finally, the arithmetic mean and standard deviation were calculated.

Statistical analysis. Normal distribution of the data was confirmed by the Kolmogorov-Smirnov test. Results were presented as a mean \pm standard deviation. The Student's t-test was performed. $\mathrm{P}$ value $<0.05$ was considered to be statistically significant.

\section{Results}

Immunohistochemical staining demonstrated that examined proteins were located in the cytoplasm of cells, while NF- $\kappa \mathrm{B}$ immunoreactivity was observed in both cytoplasm and cell nuclei.

\section{Interleukin $1 \beta$}

In the group of serous ovarian tumors IL-1 immunoreactivity was higher in borderline and malignant tumors than in benign lesions by $41 \%$ and $61 \%$, respectively (Table 1). However, the immunoexpression of IL-1 did not differ between serous malignant and borderline tumors.

In the group of mucinous ovarian tumors IL-1 immunoreactivity in borderline and malignant tumors was higher than in benign lesions by $31 \%$ and by $86 \%$, respectively, (Table 1, Figure 1). Moreover, the IL-1 expression was by $42 \%$ higher in mucinous malignant tumors than in mucinous borderline tumors.

The immunoreactivity of IL-1 in benign, borderline and malignant lesions was similar in serous and mucinous tumors (Table 1, Figure 1).

\section{Interleukin 6}

The immunoreactivity of IL-6 was observed only in serous ovarian tumors and in mucinous benign lesions (Table 1, Figure 2). No IL-6 expression was found in mucinous borderline and malignant tumors.

In serous borderline and malignant ovarian tumors IL-6 immunoreactivity was higher by $24 \%$ and $60 \%$, respectively, than in benign lesions (Table 1, Figure 2). Moreover, the IL-6 expression was by $29 \%$ higher in serous malignant lesions than in borderline tumors.

The immunoreactivity of IL-6 in benign lesions was similar in serous and mucinous tumors (Table 1, Figure 2). 
Table 1. Quantitative evaluation of protein expression in some ovarian cancer

\begin{tabular}{|l|c|c|c|c|c|c|}
\hline \multirow{2}{*}{ Protein } & \multicolumn{3}{|c|}{ Serous ovarian tumors } & \multicolumn{3}{c|}{ Mucinous ovarian tumors } \\
\cline { 2 - 7 } & $\begin{array}{c}\text { Benign } \\
\mathbf{n}=\mathbf{1 5}\end{array}$ & $\begin{array}{c}\text { Borderline } \\
\mathbf{n = 1 5}\end{array}$ & $\begin{array}{c}\text { Malignant } \\
\mathbf{n}=\mathbf{1 5}\end{array}$ & $\begin{array}{c}\text { Benign } \\
\mathbf{n = 1 5}\end{array}$ & $\begin{array}{c}\text { Borderline } \\
\mathbf{n}=\mathbf{1 5}\end{array}$ & $\begin{array}{c}\text { Malignant } \\
\mathbf{n}=\mathbf{1 5}\end{array}$ \\
\hline IL-1 & $111.5 \pm 10.1$ & $157.3 \pm 13.8^{\mathrm{c}}$ & $179.6 \pm 13.9^{\mathrm{d}}$ & $100.7 \pm 7.8$ & $131.9 \pm 11.9^{\mathrm{f}}$ & $187.2^{\mathrm{d}} \pm 14.3^{\mathrm{g}, \mathrm{h}}$ \\
\hline IL-6 & $110.2 \pm 10.6$ & $136.7 \pm 12.8^{\mathrm{c}}$ & $176.4 \pm 14.6^{\mathrm{d}, \mathrm{e}}$ & $123.3 \pm 11.1$ & - & - \\
\hline TNF- $\alpha$ & $102.4 \pm 9.8$ & $131.1 \pm 1.7^{\mathrm{c}}$ & $193.9 \pm 12.1^{\mathrm{d}, \mathrm{e}}$ & $94.2 \pm 7.7$ & $143.7 \pm 11.5^{\mathrm{f}}$ & $186.7 \pm 11.9^{\mathrm{g}, \mathrm{h}}$ \\
\hline TGF- $\beta$ & $104.1 \pm 1.4$ & $176.1 \pm 11.7^{\mathrm{c}}$ & $127.8 \pm 11.4^{\mathrm{d}, \mathrm{e}}$ & $83.1 \pm 8.8$ & $128.6 \pm 11.8^{\mathrm{b}, \mathrm{f}}$ & $138.3 \pm 14.5^{\mathrm{g}}$ \\
\hline COX-2 & $84.2 \pm 5.7$ & $154.5 \pm 12.3^{\mathrm{c}}$ & $179.9 \pm 13.5^{\mathrm{d}}$ & $104.6 \pm 9.3^{\mathrm{a}}$ & $165.3 \pm 12.6^{\mathrm{f}}$ & $195.5 \pm 11.1^{\mathrm{g}, \mathrm{h}}$ \\
\hline iNOS & $141.8 \pm 9.3$ & $172.2 \pm 9.6^{\mathrm{c}}$ & $180.5 \pm 12.8^{\mathrm{d}}$ & $128.2 \pm 8.8$ & $133.4 \pm 9.3^{\mathrm{b}}$ & $188.4 \pm 13.7^{\mathrm{g}, \mathrm{h}}$ \\
\hline NF- $\kappa$ B & $99.3 \pm 9.2$ & $164.2 \pm 11.8^{\mathrm{c}}$ & $150.6 \pm 9.2^{\mathrm{d}}$ & $139.7 \pm 10.8^{\mathrm{a}}$ & $145.4 \pm 9.5^{\mathrm{b}}$ & $147.6 \pm 9.4$ \\
\hline
\end{tabular}

Values represent mean and SEM of densitometric units. Superscripts denote statistically significant difference at $\mathrm{P}<0.05$, between following groups: abenign serous $v s$. benign mucinous tumors, bborderline serous $v s$. borderline mucinous tumors, " benign serous $v s$. borderline serous tumors, dbenign serous $v s$. malignant serous tumors, eborderline serous vs. malignant serous tumors, fbenign mucinous $v s$. borderline mucinous tumors, sbenign mucinous vs. malignant mucinous tumors, hborderline mucinous $v s$. malignant mucinous tumors
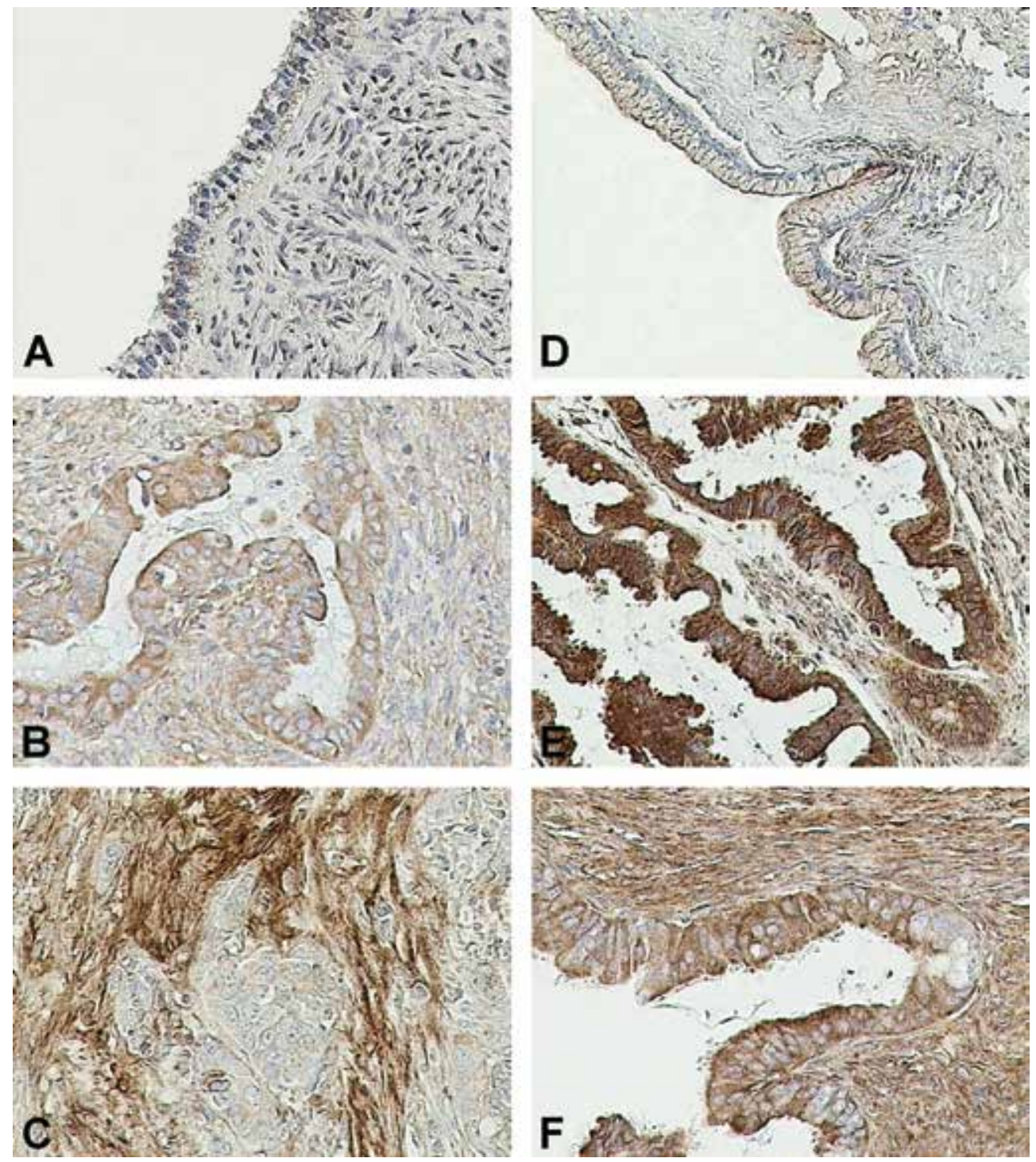

Figure 1. Immunoreactivity of IL-1 in benign (A, D), borderline $(\mathbf{B}, \mathbf{E})$ and malignant $(\mathbf{C}, \mathbf{F})$, serous $(\mathbf{A}, \mathbf{B}, \mathbf{C})$ and mucous $($ D, E, F) ovarian tumors. Magnification $\times 200$ 

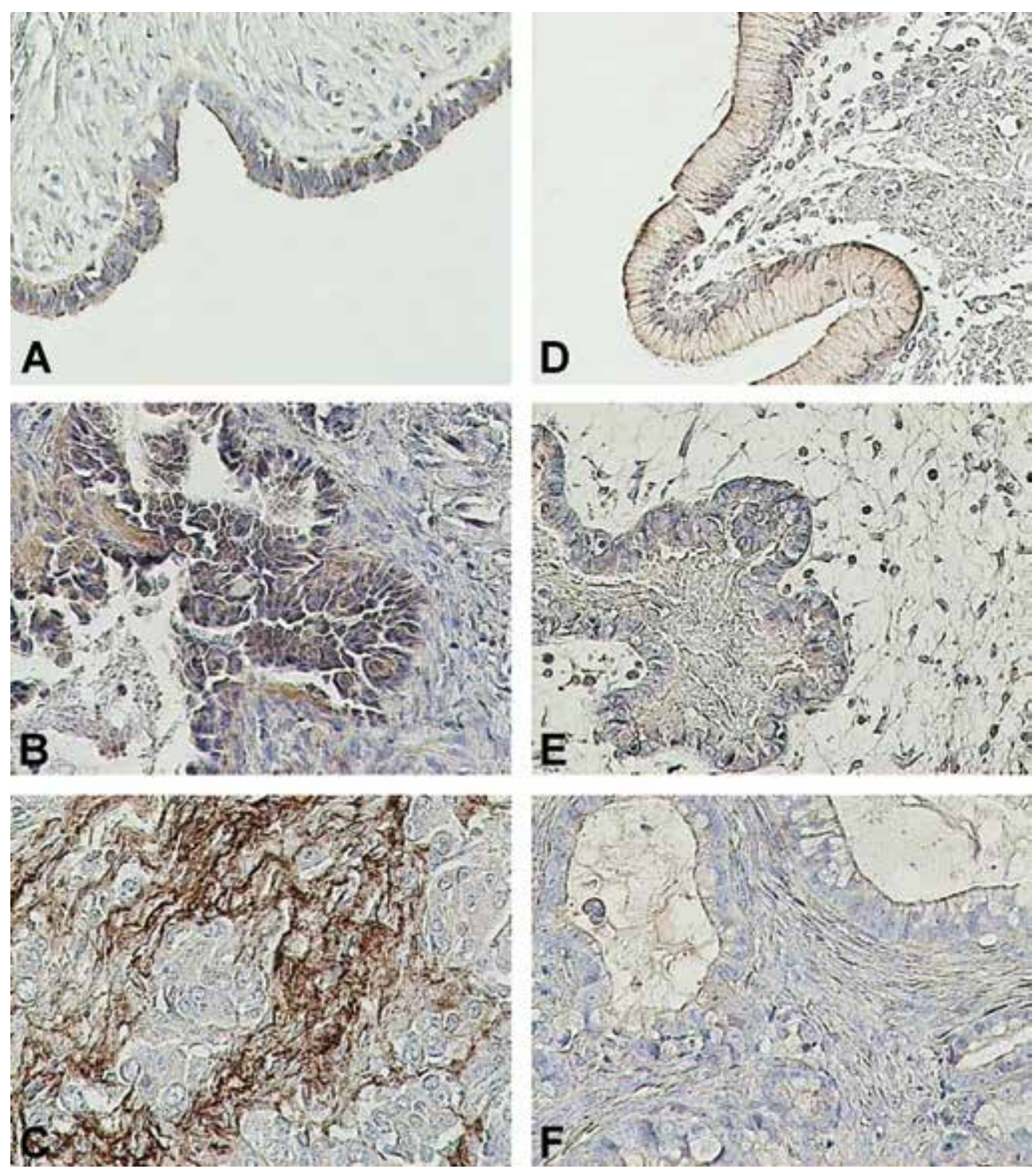

Figure 2. Immunoreactivity of IL-6 in ovarian tumors. A-F: as described for Figure 1. Magnification $\times 200$

\section{Tumor necrosis factor $\alpha$}

In serous borderline and malignant ovarian tumors TNF- $\alpha$ immunoreactivity was higher by $28 \%$ and $89 \%$, respectively, than in benign lesions (Table 1 , Figure 3). Moreover, the TNF- $\alpha$ expression in malignant serous lesions was higher by $48 \%$ than in borderline tumors.

In mucinous tumors TNF- $\alpha$ immunoreactivity in borderline and malignant tumors was higher than in benign lesions by $53 \%$ and $98 \%$, respectively (Table 1 , Figure 3). Moreover, TNF- $\alpha$ expression in malignant mucinous tumors was higher by $30 \%$ than in borderline tumors.

The immunoreactivity of TNF- $\alpha$ in benign, borderline and malignant lesions was similar in serous and mucinous tumors (Table 1, Figure 3).

\section{Transforming growth factor $\beta$}

Transforming growth factor $\beta$ immunoexpression was by $69 \%$ and $25 \%$ higher in borderline and malignant serous tumors, respectively, than in borderline tumors, and by $38 \%$ lower in serous malignant than borderline tumors (Table 1, Figure 4).

In mucinous type of ovarian tumors malignant and borderline tumors TGF- $\beta$ immunoexpression was by $66 \%$ and $55 \%$ higher than in benign tumors, respectively, and it was at similar level in malignant and borderline tumors (Table 1, Figure 4).

In benign and borderline ovarian tumors TGF- $\beta$ immunoreactivity was by $25 \%$ and $37 \%$ higher in the serous than in mucinous tumors, respectively and similar in malignant serous and mucous ovarian cancer (Table 1, Figure 4). 

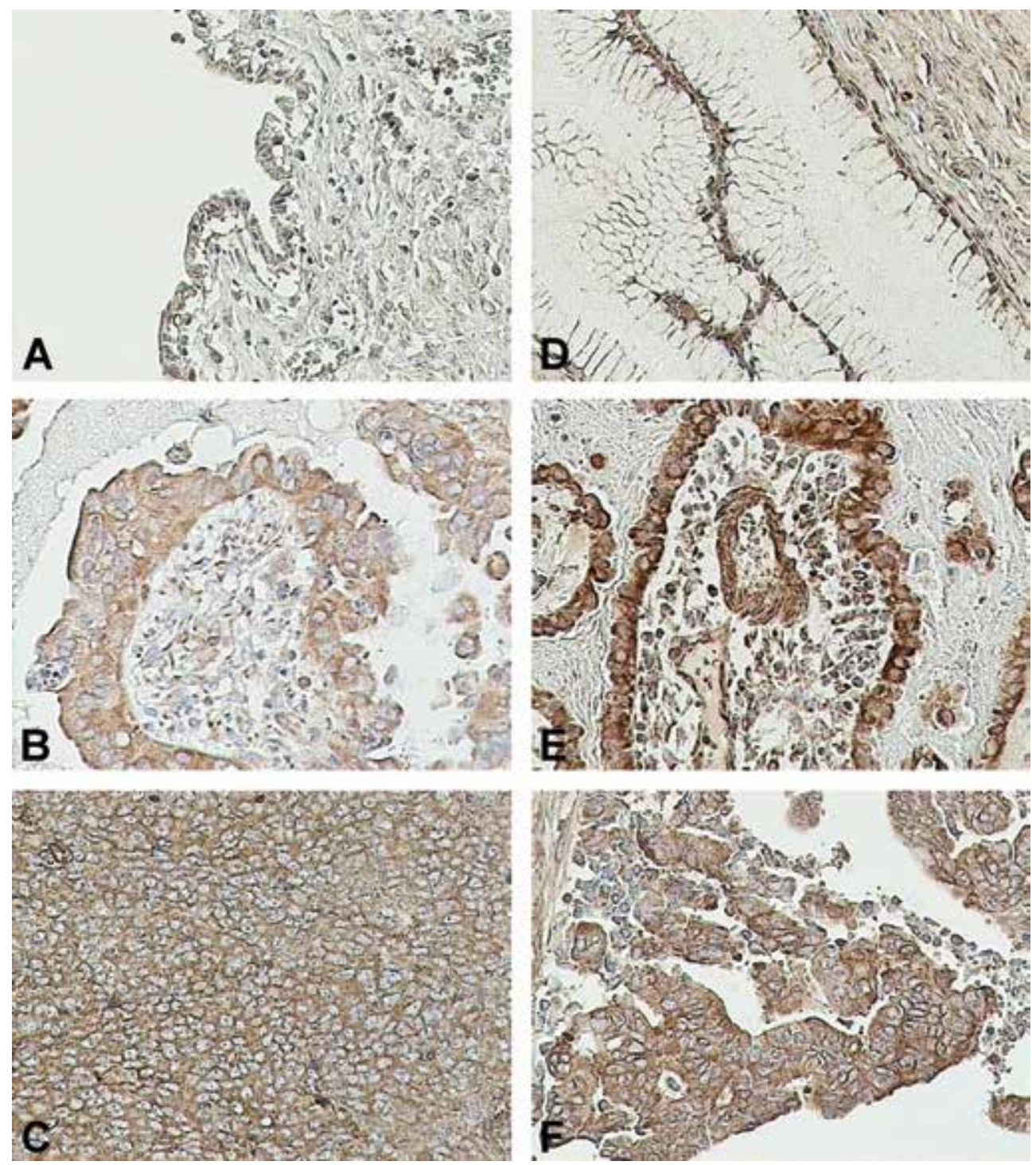

Figure 3. Immunoreactivity of TNF- $\alpha$ in ovarian tumors. A-F: as described for Figure 1. Magnification $\times 200$

\section{Cyclooxygenase 2}

In serous ovarian tumors COX-2 immunoexpression was higher in borderline and malignant tumors than in benign lesions by $83 \%$ and $113 \%$, respectively (Table 1, Figure 5).

In mucinous ovarian tumors COX-2 immunoreactivity level in borderline and malignant tumors was higher by $58 \%$ and $87 \%$ than in benign lesions, respectively, and at similar level in borderline and malignant lesions (Table 1, Figure 5).

Analysis of COX-2 immunoreactivity in benign tumors demonstrated higher immunoexpression of COX-2 protein in mucinous tumors than in serous ones, and similar expression in serous and mucinous borderline and mucinous ovarian cancer (Table 1, Figure 5).

\section{Inducible nitric oxide synthase}

In serous ovarian tumors iNOS immunoexpression was higher in borderline and malignant tumors than in benign lesions by $21 \%$ and $27 \%$, respectively, and was at similar level in borderline and malignant tumors (Table 1, Figure 6).

In malignant mucous tumors iNOS immunoreactivity was by ca. $40 \%$ higher than in benign and borderline tumors. In mucinous borderline tumors iNOS immunoreactivity was similar as in the benign tumors (Table 1, Figure 6).

The iNOS immunoreactivity in benign serous and mucinous tumors showed a tendency to a higher immunoexpression in serous tumors than in mucinous ones. In the group of serous tumors iNOS immunoreactivity was by $20 \%$ and $30 \%$ higher in borderline 

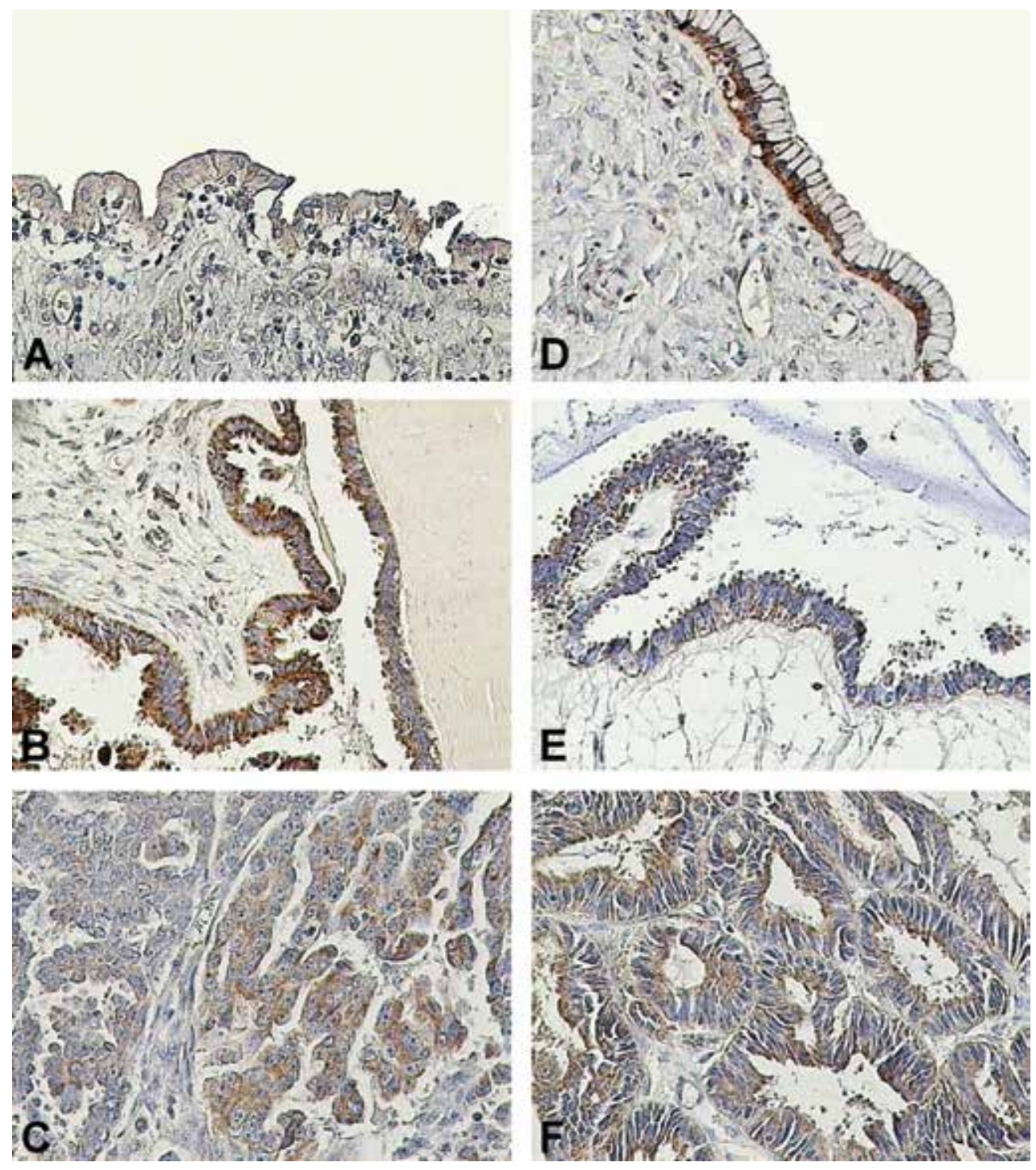

Figure 4. Immunoreactivity of TGF- $\beta$ in ovarian tumors. A-F: as described for Figure 1 . Magnification $\times 200$

and malignant tumors, respectively, than in benign lesions (Table 1, Figure 6). In the group of borderline tumors, iNOS immunoexpression in the group of mucinous tumors was by $25 \%$ lower than in serous tumors (Table 1, Figure 6).

In malignant ovarian tumors iNOS immunoexpression levels were similar in serous and mucinous tumors.

\section{Nuclear factor $\kappa B$}

In the group of serous tumors NF- $\kappa \mathrm{B}$ immunoreactivity was higher in borderline and malignant tumors than in benign lesions by $65 \%$ and $55 \%$, respectively (Table 1, Figure 7).

In mucinous ovarian tumors NF- $\kappa \mathrm{B}$ immunoexpression in benign, borderline and malignant tumors was similar (Table 1, Figure 7).
In malignant ovarian tumors NF- $\kappa \mathrm{B}$ immunoexpression did not differ significantly between serous and mucinous tumors. However, in borderline tumors the $\mathrm{NF}-\kappa \mathrm{B}$ immunoreactivity was higher in serous than in mucinous tumors. On the contrary, in benign tumors the NF- $\kappa \mathrm{B}$ immunoreactivity was higher in mucinous than in serous tumors (Table 1, Figure 7).

\section{Discussion}

Inflammation is a risk factor for ovarian cancer [31] and a hallmark of the most cancers [32]. It has been found that the inflammatory response is involved in almost all stages of tumor development [33]. Interleukin-1, one of the major pro-inflammatory cytokines, plays numerous roles in both physiological and pathological states. It has been reported that IL-1 was 

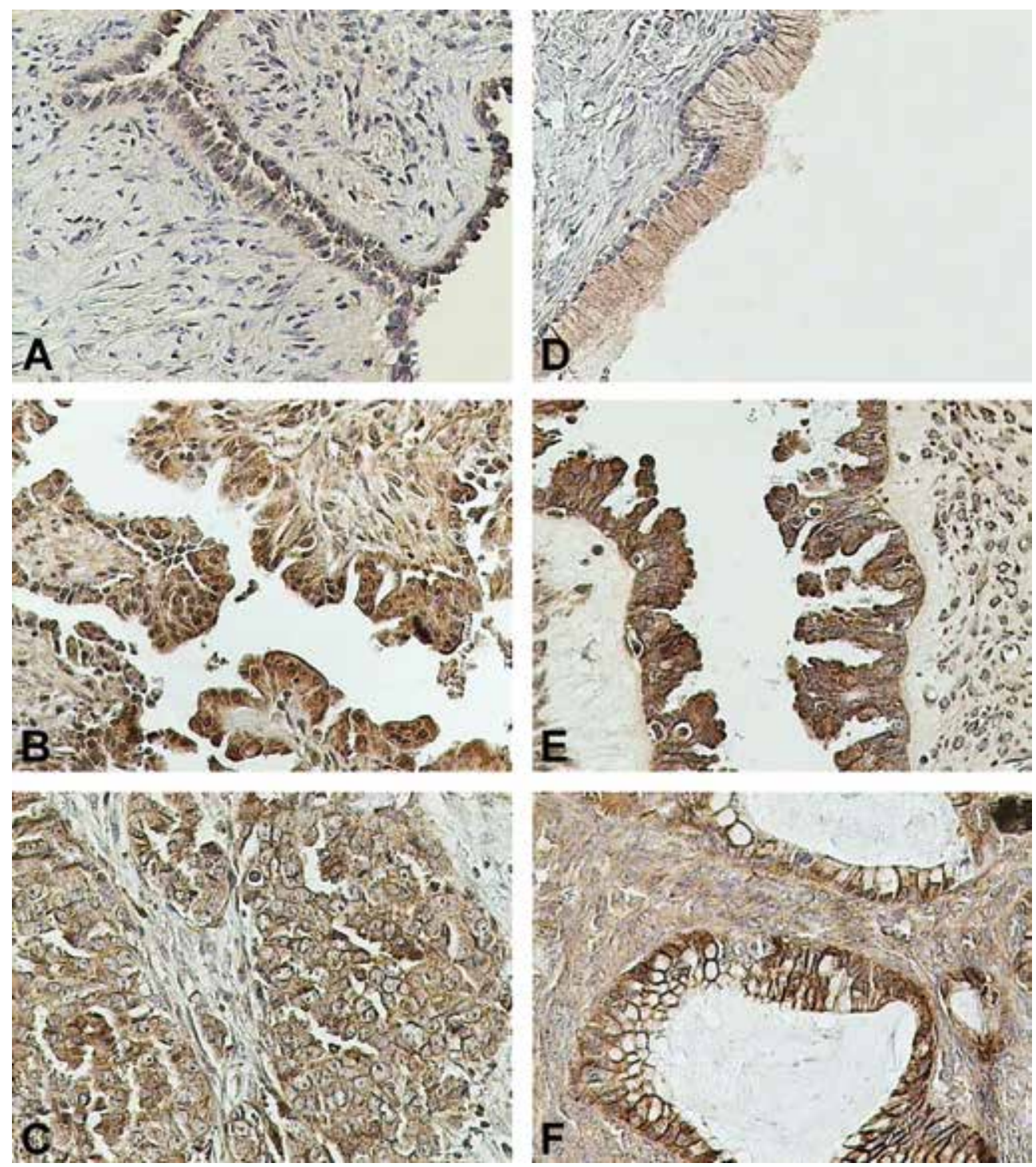

Figure 5. Immunoreactivity of iNOS in ovarian tumors. A-F: as described for Figure 1 . Magnification $\times 200$

up regulated in melanomas, breast, lung, colon, head and neck cancers. Moreover, high IL-1 concentrations within the tumor microenvironment were associated with a more virulent tumor phenotype and generally worse prognosis [5]. Production of IL-1 has been also observed in both normal and malignant epithelial ovarian cells [34], although activated immune cells in the stroma seem to be the major source of IL-1 [35]. Our study revealed that expression of IL-1 increased with the degree of malignancy and reached the highest level in both serous and mucinous metastatic carcinoma. These results confirm the previously reported tumor growth and metastasis promoting functions of IL-1. Interleukin-1 has been shown to enhance invasion capacities by increasing expression of matrix metalloproteinase-1 [36] and stimulating production of proangiogenic proteins and growth factors such as vascular growth factor [37]. Elevated levels of IL-1 may also play a role in tumor cell growth by up regulating expression of IL-6 $[38,39]$.

Interleukin-6 stimulates inflammatory cytokine production, tumor angiogenesis and tumor macrophage infiltrate in ovarian cancer. Furthermore, it may also be involved in the tumorigenic processes by increasing cancer cells capacity to secrete matrix metalloproteinase-9 [40]. Ovarian cancer cell lines cultured with IL-6 showed elevated chemotactic and chemokinetic activity and increased invasiveness [41]. Neoplastic ovarian cells routinely overexpress IL-6 in vitro [42] and greater amounts of IL-6 are present in the cystic fluid of malignant ovarian tumors when compared to benign ones [43]. Our studies revealed 


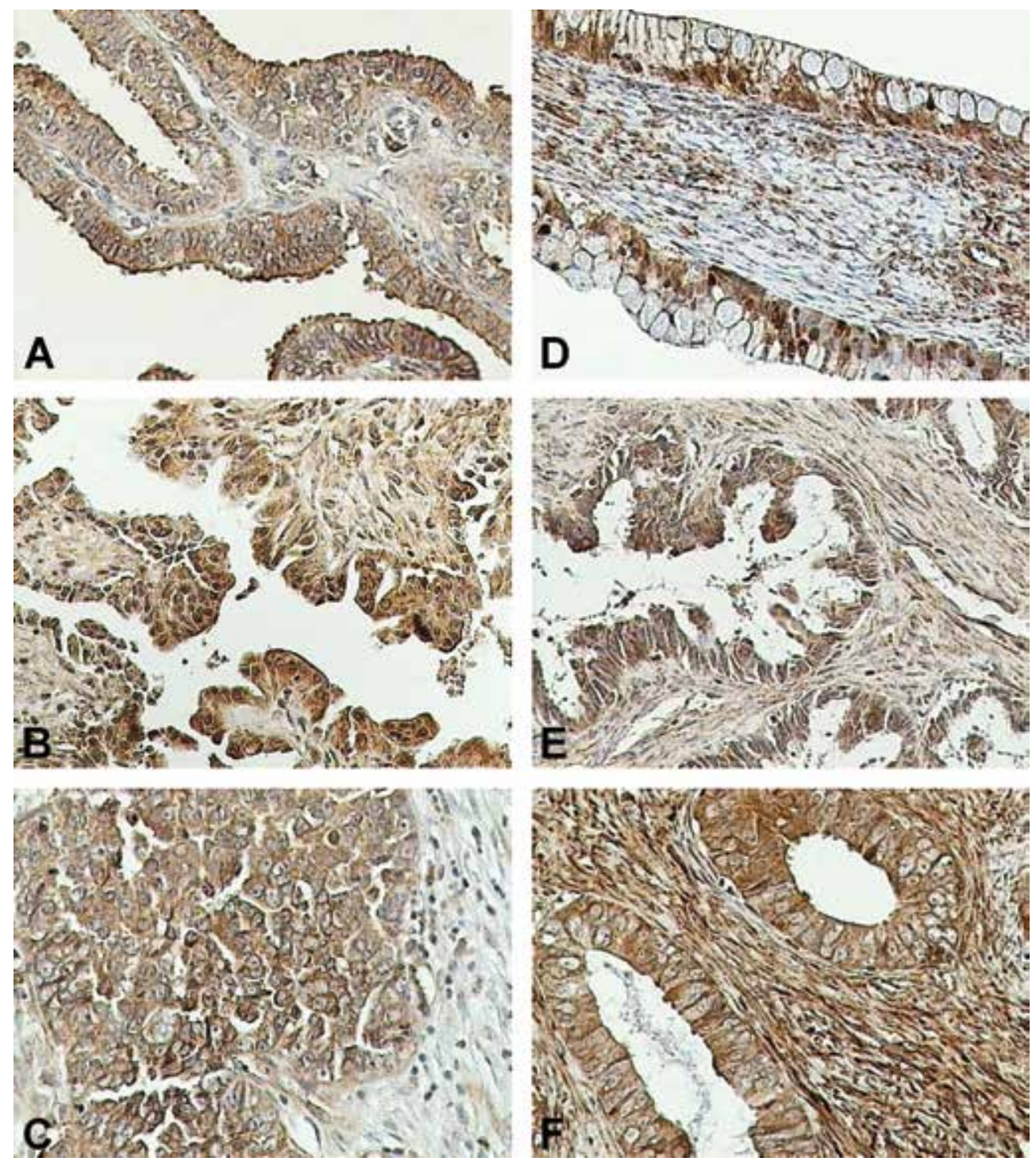

Figure 6. Immunoreactivity of COX2 in ovarian tumors. A-F: as described for Figure 1. Magnification $\times 200$

that expression of IL-6 in serous ovarian tumors was the highest in malignant lesions, while the presence of IL-6 in the mucinous tumor subtype was observed only in benign lesions. Thus, our observations suggest that the role of IL- 6 and its regulators in the pathogenesis of ovarian cancer may depend on the histological type. This observation can be very important in selecting the appropriate therapy, because it was that overexpression of IL-6 was associated with chemoresistance of ovarian cancer cells $[44,45]$, and autocrine production of IL-6 decreased responsiveness of these cells to cisplatin and paclitaxel [46].

Transforming growth factor $\beta$ is a multifunctional regulatory polypeptide with multiplicity of effects on tumor growth. It has been proposed that TGF- $\beta$ can act as both a tumor suppressor and significant stimulator of tumor progression, invasion and metastasis [10]. The actions of TGF- $\beta$ depend on several factors including cell type, growth conditions, or presence of other factors/regulators. Increased immunoexpression of TGF- $\beta$ was observed in breast, colorectal, pancreas, stomach, brain, and prostate cancer, moreover, it correlated with decreased patients' survival [47]. Therefore, it was postulated that TGF- $\beta$ may be considered a biomarker for poor prognosis in these malignancies [47]. In our study the immunoreactivity of TGF- $\beta$ in ovarian cancer depended on the histological tumor subtype and the degree of malignancy differentiation. In the case of serous tumors, the highest level of TGF- $\beta$ immunoreactivity was observed in borderline tumors suggesting a possible role of this growth factor in pathogenesis of this type 

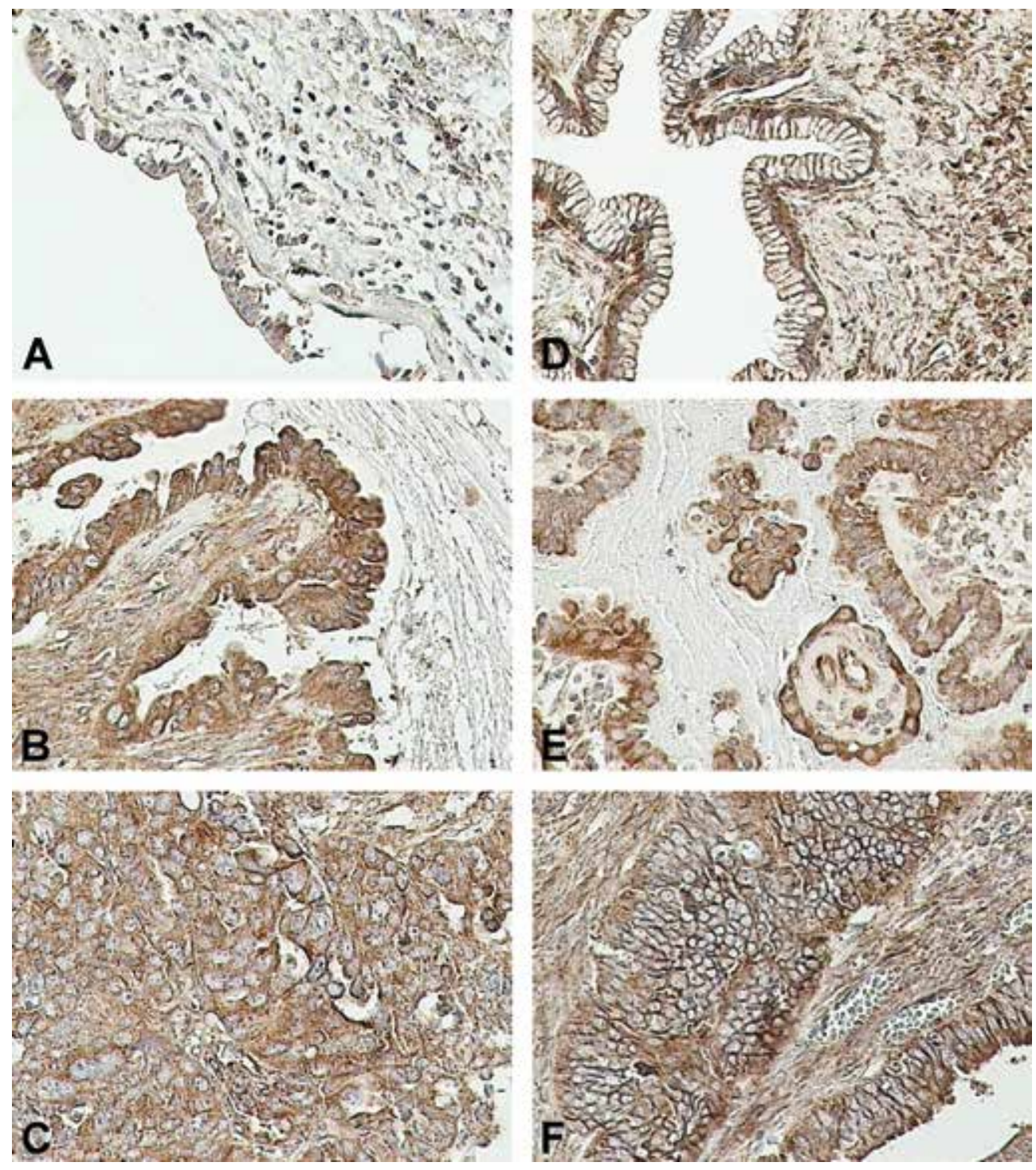

Figure 7. Immunoreactivity of $\mathrm{NF} \kappa \mathrm{B}$ in ovarian tumors. A-F: as described for Figure 1 . Magnification $\times 200$

of ovarian lesions. This observation with finding of enhanced expression of TGF- $\beta$ immunoreactivity in mucinous borderline and malignant tumors suggests that pro-oncogenic activities of TGF- $\beta$ predominate over its tumor suppressor actions and that overexpression of TGF- $\beta$ can enhance and stimulate tumor growth and malignant progression of ovarian cancer.

Tumor necrosis factor $\alpha$ is the another key mediator of inflammation and has been linked to the stimulation of tumor initiation and progression, in part by inducing the production of angiogenic factors, chemokines/cytokines and matrix metalloproteinases [48]. In previous studies, TNF- $\alpha$ mRNA and protein expression was observed predominantly within ovarian tumor epithelial islands and a positive correlation was found between tumor grade and the extent of TNF- $\alpha$ expression in serous ovarian carcinoma [49]. Immunohistochemical analysis revealed that TNF- $\alpha$ positivity was confined to malignant tissue, while the normal ovarian tissue was negative for TNF- $\alpha$ staining [50]. Szlosarek et al. reported that expression of TNF- $\alpha$ in ovarian tumors was higher compared with normal ovarian tissue, and cultured ovarian cancer cells expressed up to 1000 times more TNF- $\alpha$ mRNA than cultured normal ovarian surface epithelial cells, but TNF- $\alpha$ protein was only detected in the supernatant of tumor cell cultures. We found that immunoreactivity of TNF- $\alpha$ increased with the degree of malignancy and there was no difference in its levels between serous and mucinous tumors. Results of all these studies confirm the role of TNF- $\alpha$ in ovarian cancer development. 
Furthermore, TNF- $\alpha$ is a strong inducer of COX-2 expression by stimulating the NF- $\kappa \mathrm{B}$ system [19]. Cyclooxygenase 2 is an early response gene in inflammation and there is a growing body of evidence that COX-2 expression is important in carcinogenesis [51]. Experimental studies showed that COX-2 inhibitors blocked tumor growth [52]. Moreover, epidemiologic studies demonstrated significantly lower risk of colorectal carcinoma and several other types of cancer in people continuously taking non-steroidal anti-inflammatory drugs, which are well known COX inhibitors [53]. It was suggested that COX-2 may regulate cell proliferation, cell adhesion, apoptosis, immune surveillance, and angiogenesis during carcinogenesis [51]. Expression of COX-2 was observed in various malignancies, including cervical, gastrointestinal, head and neck, urinary bladder, and lung tumors. It was often associated with metastasis and poor prognosis [54-58] as well as with resistance to chemotherapeutic agents and radiation [59,60]. In ovarian cancer, studies have reported conflicting results regarding the COX-2 expression. Expression of COX-2 has been mostly reported to be higher in ovarian invasive carcinoma than in tumors with low malignant potential [61-65]. Our study also revealed the lowest level of COX-2 immunoreactivity in benign tumors and the highest in malignant ones. In contrast to these results, Klimp et al. [66] observed that COX-2 staining was more intense in the epithelial cells of benign and borderline tumors than in malignant tumors. The study by Dore et al. [67] indicated no expression of COX-2 in ovarian tumors. Comparing histologic subtypes, we found that the expression of COX-2 was higher in mucinous lesions than that in serous ones, but this difference was not significant in the borderline tumors. Similarly to our observations, Yoshida et al. [68] reported the lack of differences in the expression of COX-2 between serous and mucinous borderline tumors, but in contrast to our results they found lower level of COX-2 expression in mucinous benign tumors compared to serous lesions and no differences in the COX-2 expression between serous and mucinous malignant tumors. Studies by Ferrandina et al. [18] revealed opposite results indicating significantly higher percentage of COX-2 positivity in serous borderline tumors than in mucinous lesions. It is difficult to explain reasons for these discrepancies, but some authors suggest that inconsistent results between studies may be due to differences in staining assessment, differences in staining techniques, source of antibody and population differences [17, 51]. Although Özel et al. [16] failed to detect a correlation between histological type of tumor and expression of COX-2, our results confirm suggestions of Seo et al. [51] that expression of COX-2 in ovarian carcinoma is specific to histologic type of tumor and COX-2 may enhance the metastatic potential as well as tumorigenicity and may be involved in the progression of ovarian tumors [62].

Activation of COX-2 is associated with the function of inducible NOS [16]. iNOS synthesizes nitric oxide (NO), which is thought to play various roles in physiologic and pathologic conditions. The function of NO in tumor biology is complex, because it has both inhibitory and stimulatory roles in cellular processes depending on the conditions, such as the local concentration NO, presence of other regulators, and genetic make-up of the cells [69]. NO at high concentrations may be cytostatic or cytotoxic for tumor cells by causing p53-dependent cell cycle arrest and apoptosis [70]. However, NO can also promote tumor growth, metastasis and angiogenesis by upregulating vascular endothelial growth factor [14]. Expression of iNOS can be transcriptionally regulated by cytokines such as IL-1 and TNF- $\alpha$ [14], and was observed in a variety of human malignant tumors, e.g. breast [71], lung [72], prostate [73], bladder [74], and colorectal [75] cancer. Although increased expression of iNOS is common in tumors, different studies on the same types of tumors reported different results both regarding the source of iNOS and the levels of expression. The prognostic significance of iNOS in cancer is also controversial. It was suggested that iNOS expression strongly depended on histological type/grade of the tumor and tumor stage [15]. Previous studies revealed that iNOS activity was localized in ovarian malignant tumor tissue and not in benign tissue [76]. However, Klimp et al. [66] showed that borderline and benign ovarian tumors also expressed iNOS. Anttila et al. [77] indicated that iNOS expression favoured prolonged survival in epithelial ovarian cancer and mucinous tumors expressed significantly more iNOS than other types, but positive expression iNOS was not associated with increased survival in this tumor type. Results of our investigations revealed significantly higher iNOS expression in borderline and malignant serous tumors compared to benign lesions. Moreover, the level of iNOS expression was higher in serous than in mucinous borderline tumors. In the case of mucinous tumors, the highest level of iNOS immunoreactivity was observed in malignant lesions. Our findings are consistent with studies by Nomelini et al. [78] and Ali-Fehmi et al. [2] who showed that expression of iNOS was increased in malignant ovarian cancer samples compared to non-neoplastic or benign tumor samples. It was found that the epithelial ovarian cancer cell lines overexpressed iNOS and had high baseline NO levels what was associated with high levels 
of vascular endothelial growth factor production and angiogenesis induction [79]. Raspollini et al. reported that overexpression of iNOS had a negative impact on the response to chemotherapy and overall survival in patients with ovarian serous adenocarcinoma [80]. Thus, a better understanding of mechanisms which control expression and function of iNOS could be useful in the development of more effective therapies that will lead to improved cure rates and patient survival.

It has been shown that mechanisms of iNOS induction involve NF- $\kappa \mathrm{B}$ [81]. Nuclear factor $\kappa \mathrm{B}$ plays an important regulatory role in the transcription of genes that may be assigned to the categories of immunoregulatory and inflammatory genes, anti-apoptotic genes, and genes regulating proliferation [82]. A deregulated NF- $\kappa$ B pathway is thought to contribute to tumor progression. NF- $\kappa \mathrm{B}$ was found to be overexpressed in several cancers, including ovarian cancer [83-85]. Guo et al. [83] indicated that elevated $\mathrm{NF}-\kappa \mathrm{B}$ expression significantly correlated with late clinical stage and poor histological differentiation. Our study revealed higher expression of NF- $\kappa \mathrm{B}$ in borderline and malignant serous ovarian tumors compared to benign lesions, while in the case of the mucinous tumors there were no significant differences in the levels of NF- $\kappa$ B immunoreactivity between benign, borderline and malignant lesions. Ali-Fehmi et al. [2] demonstrated that NF- $\kappa$ B expression in epithelial ovarian tumors did not differ by tumor type, nor did it influence patients' outcome. However, in their study, nuclear but not cytoplasmic NF- $\kappa$ B was used for intensity grading. The classic form of NF- $\kappa \mathrm{B}$ is normally retained in cytoplasm by its interactions with inhibitor proteins $\mathrm{I} \kappa \mathrm{B} \alpha$ and $\mathrm{I} \kappa \mathrm{B} \beta$, and NF- $\kappa \mathrm{B}$ is generally considered active when it is present rather in nucleus than in cytoplasm [82]. However, the overall level of this protein may also be related to its level of activity. Annunziata et al. [86] reported that an increase in cytoplasmic NF- $\kappa \mathrm{B}$ transcription factor p50 was significantly associated with poorer patients' survival, but no association was found between NF- $\kappa \mathrm{B}$ transcription factor p65 and survival. There are five members of the mammalian NF- $\kappa \mathrm{B} / \mathrm{Rel}$ family and heterodimer composed of the p50 and 65 subunits is the classic form [82]. Therefore, we used anti-NF- $\kappa \mathrm{B}$ p65 antibodies in our study. Darb-Esfahani et al. [87] detected p65 expression mainly in the cytoplasm of ovarian carcinoma cells and, in contrast to study by Annunziata et al. [86], total p65 expression was an indicator of a worse patient outcome. Patients with overexpression of $\mathrm{p} 65 \mathrm{had}$ a significantly shorter mean survival than those with negative tumors. Results of study by Chen et al [88] provided evidences that the dual function of NF- $\kappa \mathrm{B}$, as an inhibitor or activator of apoptosis, depends on the relative levels of p65 or c-Rel subunits, respectively.

In summary, our studies have shown differences in the expression of pro-inflammatory factors and their regulators depending on the histological type of ovarian cancer and the degree of malignancy. Inflammation agents have a wide range of growth regulatory effects on cancer cells and they can directly or indirectly promote or inhibit tumor growth. Thus, better understanding of regulation of their expression in different histological types of ovarian cancer may help in developing novel strategies for ovarian cancer diagnosis and therapy.

\section{References}

1. Woolery KT, Kruk PA. Ovarian epithelial-stromal interactions: role of interleukins 1 and 6. Obstet Gynecol Int. 2011;2011:358-493.

2. Ali-Fehmi R, Semaan A, Sethi S et al. Molecular typing of epithelial ovarian carcinomas using inflammatory markers. Cancer. 2011;117:301-309.

3. Raspollini MR, Taddei GL. Tumor markers in ovarian carcinoma. Int J Gynecol Obstet. 2007;97:175-181.

4. Kuper H, Adami HO, Trichopoulos D. Infections as a major preventable cause of human cancer. J Intern Med. 2000;248: 171-183.

5. Lewis AM, Varghese $\mathrm{S}, \mathrm{Xu} \mathrm{H}$, Alexander HR. Interleukin-1 and cancer progression: the emerging role of interleukin-1 receptor antagonist as a novel therapeutic agent in cancer treatment. J Trans Med. 2006;4:48.

6. Dinarello CA. The paradox of pro-inflammatory cytokines in cancer. Cancer Metastasis Rev. 2006;25:307-313.

7. Canellada A, Alvarez I, Berod L, Gentile T. Estrogen and progesterone regulate the IL-6 signal transduction pathway in antibody secreting cells. J Steroid Biochem Mol Biol. 2008;111:255-261.

8. Hanahan D, Weinberg RA. The hallmarks of cancer. Cell. 2000;100:57-70.

9. Folkman J, Ryeom S. Is oncogene addiction angiogenesis-dependent? Cold Spring Harb Symp Quant Biol. 2005;70:389-397.

10. Jakowlew SB. Transforming growth factor- $\beta$ in cancer and metastasis. Cancer Metastasis Rev. 2006;25:435-457.

11. Kulbe H, Thompson R, Wilson JL et al. The inflammatory cytokine tumor necrosis factor-alpha generates an autocrine tumor-promoting network in epithelial ovarian cancer cells. Cancer Res. 2007;67:585-592.

12. Wu S, Meeker WA, Wiener JR, Berchuck A, Bast RC Jr, Boyer CM. Transfection of ovarian cancer cells with tumor necrosis factor-alpha (TNF-alpha) antisense mRNA abolishes the proliferative response to interleukin-1 (IL-1) but not TNF-alpha. Gynecol Oncol. 1994;53:59-63.

13. Asschert JG, Vellenga E, Ruiters MH, de Vries EG. Regulation of spontaneous and TNF/IFN-induced IL-6 expression in two human ovarian-carcinoma cell lines. Int $J$ Cancer. 1999;82:244-249.

14. Xu W, Liu LZ, Loizidou M, Ahmed M, Charles IG. The role of nitric oxide in cancer. Cell Res. 2002;12:311-320.

15. Lechner M, Lirk P, Rieder J. Inducible nitric oxide synthase (iNOS) in tumor biology: the two sides of the same coin. Semin Cancer Biol. 2005;15:277-289. 
16. Özel E, Pestereli HE, Simsek T, Erdogan G, Karaveli FS. Expression of cyclooxygenase-2 and inducible nitric oxide synthase in ovarian surface epithelial carcinomas: is there any correlation with angiogenesis or clinicopathologic parameters? Int J Gynecol Cancer. 2006;16:549-555.

17. Menczer J. Cox-2 expression in ovarian malignancies: a review of the clinical aspects. Eur J Obstet Gynecol Reprod Biol. 2009;146:129-132.

18. Ferrandina G, Zannoni GF, Ranelletti FO et al. Cyclooxygenase-2 expression in borderline ovarian tumors. Gynecol Oncol. 2004;95:46-51.

19. Sakamoto A, Yokoyama Y, Umemoto M et al. Clinical implication of expression of cyclooxygenase-2 and peroxisome proliferator activated-receptor gamma in epithelial ovarian tumors. Br J Cancer. 2004;91:633-638.

20. Yang G, Xiao X, Rosen DG et al. The biphasic role of NF-kappaB in progression and chemoresistance of ovarian cancer. Clin Cancer Res. 2011;17:2181-2194.

21. Huang Y, Johnson KR, Norris JS, Fan W. Nuclear factor-kappaB/IkappaB signaling pathway may contribute to the mediation of paclitaxel-induced apoptosis in solid tumor cells. Cancer Res. 2000;60:4426-4432.

22. Mabuchi S, Ohmichi M, Nishio Y et al. Inhibition of inhibitor of nuclear factor $-\kappa \mathrm{B}$ phosphorylation increases the efficacy of paclitaxel in in vitro and in vivo ovarian cancer models. Clin Cancer Res. 2004;10:7645-7654.

23. Mabuchi S, Ohmichi M, Nishio Y et al. Inhibition of NF $\kappa$ B increases the efficacy of cisplatin in in vitro and in vivo ovarian cancer models. J Biol Chem. 2004;279:23 477-23 485.

24. Alvero AB. Recent insights into the role of NF-kappaB in ovarian carcinogenesis. Genome Med. 2010;2:56.

25. Schauer IG, Zhang J, Xing $Z$ et al. Interleukin- $\beta$ promotes ovarian tumorigenesis through a $553 / \mathrm{NF}-\kappa \mathrm{B}-$ mediated inflammatory response in stromal fibroblasts. Neoplasia. 2013;15:409-420.

26. Niesporek S, Weichert W, Sinn B et al. NF-kappaB subunit p65/RelA expression in ovarian carcinoma: prognostic impact and link to COX-2 overexpression. Verh Dtsch Ges Pathol. 2007;91:243-249.

27. Pikarsky E, Porat RM, Stein I et al. NF- $\kappa$ B functions as a tumor promoter in inflammation-associated cancer. Nature. 2004;431:461-466.

28. Bell DA. Origins and molecular pathology of ovarian cancer. Mod Pathol. 2005;18(Suppl 2):S19-S32.

29. Shih IeM, Kurman RJ. Ovarian tumorigenesis: a proposed model based on morphological and molecular genetic analysis. Am J Pathol. 2004;164:1511-1518.

30. Read NG, Rhodes PC. Techniques for image analysis. In: Beesley JE, ed. Immunocytochemistry. A practical approach. IRL Press: Oxford Univ. Press; 1993:127-149.

31. Ness RB, Cottreau C. Possible role of ovarian epithelial inflammation in ovarian cancer. $J$ Natl Cancer Inst. 1999;91:1459-1467.

32. Hanahan D, Weinberg RA. Hallmarks of cancer: the next generation. Cell. 2011;144:646-674.

33. Grivennikov SI, Greten FR, Karin M. Immunity, inflammation, and cancer. Cell. 2010;140:883-899.

34. Auersperg N, Wong AS, Choi KC, Kang SK, Leung PC. Ovarian surface epithelium: biology, endocrinology, and pathology. Endocr Rev. 2001;22:255-288.

35. Ziltener HJ, Maines-Bandiera S, Schrader JW, Auersperg N. Secretion of bioactive interleukin-1, interleukin-6, and colonystimulating factors by human ovarian surface epithelium. Biol Reprod. 1993;49:635-641.
36. Denkert C, Koch I, Berger S, Köbel M, Siegert A, Hauptmann S. Cytokine-suppressive anti-inflammatory drugs (CSAIDs) inhibit invasion and MMP-1 production of ovarian carcinoma cells. Cancer Lett. 2003;195:101-109.

37. Stadlmann S, Amberger A, Pollheimer J et al. Ovarian carcinoma cells and IL-1beta-activated human peritoneal mesothelial cells are possible sources of vascular endothelial growth factor in inflammatory and malignant peritoneal effusions. Gynecol Oncol. 2005;97:784-789.

38. Offner FA, Obrist P, Stadlmann S et al. IL-6 secretion by human peritoneal mesothelial and ovarian cancer cells. Cytokine. 1995;7:542-547.

39. Coward J, Kulbe H, Chakravarty P et al. Interleukin-6 as a therapeutic target in human ovarian cancer. Clin Cancer Res. 2011;17:6083-6096.

40. Rabinovich A, Medina L, Piura B, Segal S, Huleihel M. Regulation of ovarian carcinoma SKOV-3 cell proliferation and secretion of MMPs by autocrine IL-6. Anticancer Res. 2007;27:267-272.

41. Obata NH, Tamakoshi K, Shibata K, Kikkawa F, Tomoda Y. Effects of interleukin-6 on in vitro cell attachment, migration and invasion of human ovarian carcinoma. Anticancer Res. 1997; 17:337-342.

42. Asschert JG, Vellenga E, Hollema $\mathrm{H}$, van der Zee AG, de Vries EG. Expression of macrophage colony-stimulating factor (M-CSF), interleukin-6 (IL-6), interleukin-1 beta (IL-1 beta), interleukin-11 (IL-11) and tumor necrosis factor-alpha (TNF-alpha) in p53-characterised human ovarian carcinomas. Eur J Cancer. 1997;33:2246-2251.

43. van der Zee AG, de Cuyper EM, Limburg PC et al. Higher levels of interleukin-6 in cystic fluids from patients with malignant versus benign ovarian tumors correlate with decreased hemoglobin levels and increased platelet counts. Cancer. 1995;75:1004-1009.

44. Scambia G, Testa U, Benedetti Panici P et al. Prognostic significance of interleukin 6 serum levels in patients with ovarian cancer. Br J Cancer. 1995;71:354-356.

45. Penson RT, Kronish K, Duan Z et al. Cytokines IL-1beta, IL-2, IL-6, IL-8, MCP-1, GM-CSF and TNFalpha in patients with epithelial ovarian cancer and their relationship to treatment with paclitaxel. Int J Gynecol Cancer. 2000;10:33-41.

46. Wang Y, Niu XL, Qu Y et al. Autocrine production of interleukin-6 confers cisplatin and paclitaxel resistance in ovarian cancer cells. Cancer Lett. 2010;295:110-123.

47. Parekh TV, Gama $\mathrm{P}$, Wen $\mathrm{X}$ et al. Transforming growth factor $\beta$ signaling is disabled early in human endometrial carcinogenesis concomitant with loss of growth inhibition. Cancer Res. 2002;62:2778-2790.

48. Yan L, Anderson GM, DeWitte M, Nakada MT. Therapeutic potential of cytokine and chemokine antagonists in cancer therapy. Eur J Cancer. 2006;42:793-802.

49. Naylor MS, Stamp GW, Foulkes WD, Eccles D, Balkwill FR. Tumor necrosis factor and its receptors in human ovarian cancer. Potential role in disease progression. J Clin Invest. 1993;91:2194-2206.

50. Hassan MI, Kassim SK, Saeda L, Laban M, Khalifa A. Ovarian cancer-induced immunosuppression: relationship to tumor necrosis factor-alpha (TNF-alpha) release from ovarian tissue. Anticancer Res. 1999;19:5657-5662.

51. Seo SS, Song YS, Kang DH et al. Expression of cyclooxygenase-2 in association with clinicopathological prognostic factors and molecular markers in epithelial ovarian cancer. Gynecol Oncol. 2004;92:927-935.

52. Gasparini G, Longo R, Sarmiento R, Morabito A. Inhibitors of cyclo-oxygenase 2: a new class of anticancer agents? Lancet Oncol. 2003;4:605-615. 
53. Meier CR, Schmitz S, Jick H. Association between acetaminophen or nonsteroidal antiinflammatory drugs and risk of developing ovarian, breast, or colon cancer. Pharmacotherapy. 2002;22:303-309.

54. Ryu HS, Chang KH, Yang HW, Kim MS, Kwon HC, Oh KS. High cyclooxygenase-2 expression in stage IB cervical cancer with lymph node metastasis or parametrial invasion. Gynecol Oncol. 2000;76:320-325.

55. Chen WS, Wei SJ, Liu JM, Hsiao M, Kou-Lin J, Yang WK. Tumor invasiveness and liver metastasis of colon cancer cells correlated with cyclooxygenase-2 (COX-2) expression and inhibited by a COX-2-selective inhibitor, etodolac. Int J Cancer. 2001;91:894-899.

56. Gallo O, Franchi A, Magnelli L et al. Cyclooxygenase-2 pathway correlates with VEGF expression in head and neck cancer. Implications for tumor angiogenesis and metastasis. Neoplasia. 2001;3:53-61.

57. Shirahama T, Arima J, Akiba S, Sakakura C. Relation between cyclooxygenase-2 expression and tumor invasiveness and patient survival in transitional cell carcinoma of the urinary bladder. Cancer. 2001;92:188-193.

58. Khuri FR, Wu H, Lee JJ et al. Cyclooxygenase-2 overexpression is a marker of poor prognosis in stage I non-small cell lung cancer. Clin Cancer Res. 2001;7:861-867.

59. Ratnasinghe D, Daschner PJ, Anver MR et al. Cyclooxygenase-2, P-glycoprotein-170 and drug resistance; is chemoprevention against multidrug resistance possible? Anticancer Res. 2001;21:2141-2147.

60. Gaffney DK, Holden J, Zempolich K, Murphy KJ, Dicker AP, Dodson M. Elevated COX-2 expression in cervical carcinoma: reduced cause-specific survival and pelvic control. Am J Clin Oncol. 2001;24:443-446.

61. Denkert C, Köbel M, Pest S et al. Expression of cyclooxygenase 2 is an independent prognostic factor in human ovarian carcinoma. Am J Pathol. 2002;160:893-903.

62. Li M, Qi SY, Wang Y, Feng SX, Zhang BZ, Wang R. Expression and clinical significance of vascular endothelial growth factor, cyclooxygenase-2, and Bcl-2 in borderline ovarian tumors. Arch Gynecol Obstet. 2005;2721:48-52.

63. Lee JS, Choi YD, Lee JH et al. Expression of cyclooxygenase- 2 in epithelial ovarian tumors and its relation to vascular endothelial growth factor and p53 expression. Int J Gynecol Cancer. 2006;16:247-253.

64. Singhal PK, Spiegel G, Driscoll D, Odunsi K, Lele S, Rodabaugh KJ. Cyclooxygenase 2 expression in serous tumors of the ovary. Int J Gynecol Pathol. 2005;24:62-66.

65. Matsumoto Y, Ishiko O, Deguchi M, Nakagawa E, Ogita S. Cyclooxygenase-2 expression in normal ovaries and epithelial ovarian neoplasms. Int J Mol Med. 2001;8:31-36.

66. Klimp AH, Hollema H, Kempinga C, van der Zee AG, de Vries EG, Daemen T. Expression of cyclooxygenase-2 and inducible nitric oxide synthase in human ovarian tumors and tumor-associated macrophages. Cancer Res. 2001;61:7305-7309.

67. Doré M, Côté LC, Mitchell A, Sirois J. Expression of prostaglandin $\mathrm{G} / \mathrm{H}$ synthase type 1 , but not type 2 , in human ovarian adenocarcinomas. J Histochem Cytochem. 1998;46:77-84.

68. Yoshida A, Sarian LO, Andrade LA, Pignataro F, Pinto GA, Derchain SF. Cell proliferation activity unrelated to COX-2 expression in ovarian tumors. Int J Gynecol Cancer. 2007;17:607-614.

69. Lala PK, Chakraborty C. Role of nitric oxide in carcinogenesis and tumor progression. Lancet Oncol. 2001;2:149-156.

70. Ambs S, Hussain SP, Harris CC. Interactive effects of nitric oxide and the p53 tumor suppressor gene in carcinogenesis and tumor progression. FASEB J. 1997;11:443-448.
71. Vakkala M, Kahlos K, Lakari E, Pääkkö P, Kinnula V, Soini Y. Inducible nitric oxide synthase expression, apoptosis, and angiogenesis in in situ and invasive breast carcinomas. Clin Cancer Res. 2000;6:2408-2416.

72. Marrogi AJ, Travis WD, Welsh JA et al. Nitric oxide synthase, cyclooxygenase 2 , and vascular endothelial growth factor in the angiogenesis of non-small cell lung carcinoma. Clin Cancer Res. 2000;6:4739-4744.

73. Aaltoma SH, Lipponen PK, Kosma VM. Inducible nitric oxide synthase (iNOS) expression and its prognostic value in prostate cancer. Anticancer Res. 2001;21:3101-3106.

74. Swana HS, Smith SD, Perrotta PL, Saito N, Wheeler MA, Weiss RM. Inducible nitric oxide synthase with transitional cell carcinoma of the bladder. J Urol. 1999;161:630-634.

75. Kojima M, Morisaki T, Tsukahara Y et al. Nitric oxide synthase expression and nitric oxide production in human colon carcinoma tissue. J Surg Oncol. 1999;70:222-229.

76. Thomsen LL, Sargent JM, Williamson CJ, Elgie AW. Nitric oxide synthase activity in fresh cells from ovarian tumor tissue: relationship of enzyme activity with clinical parameters of patients with ovarian cancer. Biochem Pharmacol. 1998;56:1365-1370.

77. Anttila MA, Voutilainen K, Merivalo S, Saarikoski S, Kosma VM. Prognostic significance of iNOS in epithelial ovarian cancer. Gynecol Oncol. 2007;105:97-103.

78. Nomelini RS, de Abreu Ribeiro LC, Tavares-Murta BM, Adad SJ, Murta EF. Production of nitric oxide and expression of inducible nitric oxide synthase in ovarian cystic tumors. Mediators Inflamm. 2008;2008:186 584.

79. Malone JM, Saed GM, Diamond MP, Sokol RJ, Munkarah AR. The effects of the inhibition of inducible nitric oxide synthase on angiogenesis of epithelial ovarian cancer. Am J Obstet Gynecol. 2006;194:1110-1118.

80. Raspollini MR, Amunni G, Villanucci A et al. Expression of inducible nitric oxide synthase and cycloxygenase- 2 in ovarian cancer: correlation with clinical outcome. Gynecol Oncol. 2004;92:806-812.

81. Taylor BS, de Vera ME, Ganster RW et al. Multiple NF -kappaB enhancer elements regulate cytokine induction of the human inducible nitric oxide synthase gene. J Biol Chem. 1998;273:15 148-15 156.

82. Karin M, Cao Y, Greten FR, Li ZW. NF-kappaB in cancer: from innocent bystander to major culprit. Nat Rev Cancer. 2002;2:301-310.

83. Guo RX, Qiao YH, Zhou Y, Li LX, Shi HR, Chen KS. Increased staining for phosphorylated AKT and nuclear factor-kappaB p65 and their relationship with prognosis in epithelial ovarian cancer. Pathol Int. 2008;58:749-756.

84. Plewka A, Madej P, Plewka D et al. Immunohistochemical localization of selected pro-inflammatory factors in uterine myomas and myometrium in women of various ages. Folia Histochem Cytobiol. 2013;51:73-83.

85. Sovak MA, Bellas RE, Kim DW et al. Aberrant nuclear factor-kappaB/Rel expression and the pathogenesis of breast cancer. J Clin Invest. 1997;100:2952-2960.

86. Annunziata CM, Stavnes HT, Kleinberg L et al. Nuclear factor kappaB transcription factors are coexpressed and convey a poor outcome in ovarian cancer. Cancer. 2010;116:3276-3284.

87. Darb-Esfahani S, Sinn BV, Weichert W et al. Expression of classical NF-kappaB pathway effectors in human ovarian carcinoma. Histopathology. 2010;56:727-739.

88. Chen X, Kandasamy K, Srivastava RK. Differential roles of RelA (p65) and c-Rel subunits of nuclear factor kappa B in tumor necrosis factor-related apoptosis-inducing ligand signaling. Cancer Res. 2003;63:1059-1066. 